\title{
Predicaments of Communication, Argument, and Power: Towards a Critical Theory of Controversy
}

\section{G. Thomas Goodnight University of Southern California}

\begin{abstract}
A critical theory of controversy would require the integration of the normative study of argumentation with critical studies of practices. Jürgen Habermas has made a substantial contribution to such a project by embedding argumentation in a theory of communication, while critically engaging academic and public debates. This essay explicates core concepts in Habermas's theory of argumentation, including his distinction between theory and practice, the different validity requirements for argumentation in general, the norms of moral and ethical-political argumentation and of bargaining. Argument predicaments are posited as ways to discover and assess different types of validity claims competing as "the force of the better argument". Habermas's criticism of "administrative power" and "communicative power" illustrates a potential yield of critical inquiry into social controversy.
\end{abstract}

Résumé: Une théorie critique de la controverse demande l'intégration de l'étude normative de l'argumentation et des études critiques de la pratique. Jürgen Habermas a contribué substantiellement à un tel projet. En participant à des débats académiques et publiques, il a pris soin $d$ ' insérer l'argumentation dans une théorie globale de la communication. Cet essai explique les concepts clés dans la théorie de l'argumentation d'Habermas: la distinction entre la théorie et la pratique, les critères différents de validité de l'argumentation, les normes de l'argumentation éthique et politique et la négociation. Les problématiques de l'argumentation sont exprimées de manière à découvrir et évaluer les stratégies compétitives dans le champ de l'argumentation. La critique des concepts "pouvoirs administratifs" et "pouvoirs communicatifs" d" Habermas s'avère fructueuse pour l'étude critique de la controverse sociale.

Keywords: communication, argument, Habermas, social theory, controversy, discourse ethics, public sphere.

\section{Introduction}

The process of introducing Habermas to students of argumentation, Thomas Farrell observed in 1979, has been going on for some time now. Then, it was agreed that logical positivism had not offered a comprehensive view of reasoning, but a full alternative had yet to take shape (Cox and Willard, 1982; van Eemeren, et al., 1996). Efforts were underway, however. Notably, Arne Naess (1953) recovered the value of two-sided reasoning; Stephen Toulmin's The Uses of Argument (1958) broke open ground for the resurgence of practical argumentation; and Chaim Perelman and L. Olbrechts-Tyteca's (1969) idea of the "universal audience" raised 
anew the relationship between rhetoric, the interests of justice, and the openness of argument to ideal norms. It was in this context that Jürgen Habermas's theorizing of knowledge and human interests appeared attractive (1971; 1973; 1979). Similar to Karl Popper with his three-world theory, Habermas "assumes that we exist simultaneously in (1) an external world of states of affairs and objects; (2) an internal world of ideals, thoughts, emotions; and (3) a normative world of intersubjectively determined norms and values" (Holub, 1991,13). In each world, argument-both as a presupposition of, and necessary complement to, communication-has a distinct and progressive role to play. Uniquely, Habermas expanded the domain of argument by calling attention to the diverse, critically emergent, and autonomous constitution of communicative reason across the expert and public, social and private, valid and pathological domains of communication in the modern world (Burleson, 1979; Cushman and Dietrich, 1979, Wenzel, 1979).

A comprehensive theory of argumentation is articulated succinctly in the first volume of Habermas's magisterial work, $A$ Theory of Communicative Action (1984, $8-42 ; 1987)$. In subsequent books, such as Moral Consciousness and Communicative Action (1990), Justification and Application (1993), and Postmetaphysical Thinking (1992), these basic ideas are modified and elaborated. The core concepts remain intact, however. What distinguishes the evolution of Habermas's contribution to argumentation studies is his mobilization of a philosophical stance in the service of defending a communication orientation, debating not only fellow academicians but also entering into the realm of public controversy. Just as the English-language publication of his influential Structural Transformation of the Public Sphere (1989/1962) sparked a debate throughout the 1990s on the history and practices of public argument (Calhoun, 1992; Goodnight and Hingstman, 1997, 351-370), so Between Facts and Norms (1996) heralded a productive interdisciplinary discussion on deliberative democracy. Habermas deploys his views of communication to engage major social controversies concerning terrorism (Borradori, 2003), genetics (Habermas, 2003), religion (Habermas, 2002ab), the European Union (Habermas, 2001b), human rights (Habermas, 1998) and postnationalism (Habermas, 2001).

The dialectical positioning of a theory of argument against practice is in line with the aims of critical social theory (Bernstein, 1976). A member of the second generation of the Frankfurt School, Habermas has made contributions that can best be described as constituting "explanatory, normative, practical and self-reflexive" studies of critical reason (Bohman, 1995a, 170). Social theory has explanatory aims; chief among them are to describe the practices of reason in society and its institutions, and to seat such descriptions within the ontogenetic development of the individual and the open-ended history of humanity. Thus Habermas explores the evolution of reason within the contexts of cognitive development and changing social formations and institutional practices and processes. At the same time, his theory of argumentation is normative, and so critical of current limits to 
structures of reason. Critique centers on the excesses of the market and misuse of state power contrasted with the needs of social welfare and justice. The practical end of social theory includes the provision of a better self-understanding for those "who may want to improve the social conditions that the theory negatively evaluates" (ibid.). This requirement makes innovation-discovery of new sensitivities or sensibilities - an aspiration of critical theory. Finally, a social theory of argument is "self-reflexive". Theorists are enjoined to find in their engagements with reason an invitation to enter academic discussions and public disputes from a critical, communicative perspective. Therefore, Habermas participates in contemporary public controversies of global scope, always with an eye toward positions that open up or close off possibilities of consensus building through mutual understanding. In sum, "The ultimate goal of [social theory] is to link theory and practice, to provide insight, and to empower subjects to change their oppressive circumstances and achieve human emancipation, a rational society that satisfies all human needs and powers" (Bohman, 1995b. 279).

In this essay, I wish to elucidate the dialectical qualities of a social theory of argumentation by reading Habermas's theory of argument against one of his major interventions into controversy, the complex relation between "communicative power" and "administrative power", largely articulated in Between Facts and Norms (1996). The essay proceeds to (1) locate Habermas on the familiar terrain of argumentation theory, (2) position his work as a response to issues of communication raised by modernity, (3) explicate a core concept, "validity", (4) illustrate how differential validity claims shape alternative forms of argument, and (5) explore an important critical intervention where Habermas deploys his theory of argumentation in the interests of engaging democratic practice. My contention is that Habermas's theory of argumentation enters into critical practice through describing, interpreting, evaluating and intervening into social controversy. At the core of critical intervention is the argumentative predicament-situations where competing demands for validity surface and problematize communication. In predicaments, multidirectional, recursive vectors driving the "force of the better argument" emerge; for instance, validity conditions that simultaneously invite reflection, yet demand resolution among interlocutors. The essay concludes with a rationale for developing further social theory and critical studies in argumentation.

\section{Process, Product, and Procedure}

Theories of argumentation are inevitably characterized by distinctions drawn among the practices of human reasoning, and in the human sciences these categories focus a long-standing discussion over the theory and practice, the ideals and craft, of argumentation. Aristotle's distinctions among forms of reasoning drew equations between the type of argumentation engaged in and the ends pursued. A podictic argument is the product of science, and its claims are constituted by strictures on observation, classification, and the laws of inference. Dialectical argument is the 
procedure of criticizing opinions within ambits of progressively more generalized claims. Rhetorical argument is a process of discovery of the best available reasons that inform and outfit citizens for the classical public sphere. Aristotle's distinctions were translated into modern form by Joseph Wenzel who noted that those exchanges which human beings understand to be arguments take the perspective of product, procedure or process (Wenzel, 1990; 1993). Borrowing from the perspectivism of Wayne Brockriede $(1975,1977)$, Wenzel observes that any specific argumentative engagement could be entered from one of these orientations. The core of Habermas's theory of argumentation rests on these very distinctions, but his definitions reflect a decentered neo-Kantian philosophy rather than a classical or traditional perspective. Habermas writes:

The fundamental intuition connected with argumentation can best be characterized from the process perspective by the intention of convincing a universal audience and gaining general assent for an utterance; from the procedural perspective, by the intention of ending a dispute about hypothetical validity claims with a rationally motivated agreement; and from the product perspective by the intention of grounding or redeeming a validity claim with arguments (1984, 26; emphasis removed).

The perspectives of process, procedure or product are rendered by Habermas into a typology that distinguishes the forms of reason by differentially interlacing cognition and communication. Scientific (formerly apodictic) argument, for instance, is based on a commitment to reason posited as a fallibilistic claim to knowledge of the objective world; truth is held to the standard of defensible assertion, its tests vetted within a deep background of intersubjective consensus. Dialectic is a procedure for ascertaining conviction governed by the "hypothetical attitude", a suspension of the pressures of action in favor of reciprocal questioning of taken-for-granted norms or values. Rhetoric, properly deployed, is the influence achieved in the service of Perelman's universal audience (Rehg, 1997, 361). Publicity in the interest of dissent and civil disobedience, advocacy of values within the processes of fair bargaining, and even polemical exchange as a means of accomplishing cross-cultural recognition - all these partially strategic efforts fall under the rubric of acceptable processes of influence. Situated acts of communication entwine propositional, relational, and persuasive potential in any particular "communicative action" (Pusey, 1987, 80); should agreement as to the rules of the game become contested or break down altogether, it would seem, social controversy ensues.

\section{Modern Terms of Engagement}

"We engage in argumentation with the intention of convincing one another of the validity claims proponents raise for their statements and are ready to defend against opponents. The practice of argumentation sets in motion a cooperative competition for the better argument where the orientation to the goal of a communicatively 
reached agreement unites participants from the outset" (Habermas, 1998, 44). In this process "what counts as a good or bad argument can itself become the topic for discussion" (ibid.). Any modern theory of argument renders the rules of argument transparent to analysis, submits the authority of reason to reflexive claims of justification, and critically addresses the multiplicity of practices by exploring the relation between form and function. The modern view rests upon, and transforms, a very old distinction.

Habermas's differentiation between communicative action and argumentation reworks the classical distinction between doxa, or common opinion, and episteme, refined knowledge. "Communicative action" is a term deployed to describe the rationality potential of everyday social interaction. The everyday is not what it used to be, of course. In modern societies, encounters between speakers and hearers are different than in traditional societies. The alteration of processes of socialization, social reproduction, and planning have transformed traditional village society to modern city life to the bustling interplay of technology, legal-economic systems, and circulating flow of the megapolis. The "doxa" based on communal life, static social arrangements, and traditional authority has not been entirely diluted, but to be part of a modern world requires human adaptation to and participation in accelerated change. The habits of living, though sometimes threatened by the modern "systems world" (Habermas, 1987), always reshape themselves into a lifeworld for an individual or community. An irreversible condition of modernity, however, is that everyone lives side by side with strangers. The others encountered in urban circulation may or may not share one's frames of experience, values, or substantive commitments. In a pluralistic society, received opinion does play its role in determining diverse loyalties, different preferences, distinctive outlooks; nevertheless communication serves us well most of the time as a means of translation that enables the complicated business of urban life to succeed routinely. Habermas's theory of argumentation is written for precisely our world of continuing departure from tradition. Argumentation plays a crucial role in underwriting modern communicative life, where at some point in any everyday interaction attributed reasonableness may be disturbed and efforts at coordination rendered puzzling by misattributed intentions. In such cases, argument plays the role of a critical discussion that repairs, and sometimes deepens, our discourses thereby reenabling interactions and confirming the everydayness of the everyday.

The doxa of a modern world is highly vested in the varied kinds of speech activities. All "serious" engagement between a speaker and a hearer has a "binding" or "bonding" power. Speaking invites "recognition", or an understanding of what another person means, which in turn creates or affirms an interpersonal relationship, a "new social fact". "Mutual understanding" is an achievement whereby reasons are rendered reciprocal and transparent between interlocutors. Any ordinary statement in this process can be understood as true, accepted as right, and trusted as sincere because words uttered appear as an act meant to communicate. 
The self-evident meaning is underwritten by a "guarantee" that a listener routinely attributes to a speaker; to wit, if called upon she or he can make sense by mustering support or "good reasons" for an uttered claim. A speaker's attempts to communicate are "worthy of recognition" if he "guarantee[s] that he will, if necessary, make efforts to redeem the claim that the hearer has accepted" (Habermas, 1990, 58). Conversely, in making an "offer" of a meaningful statement "obligations are assumed that have consequences for the interaction" (ibid., 59). To listen is to attribute a burden of proof to the speaker that his or her statement is meaningful; to speak meaningfully is to be willing to fulfill the burden of proof with additional reasons that secure a claim to reason. Argument ensues when the flow of communication is interrupted with a question or objection that cashes in the guarantee of meaning. The kinds of claims made on meaning vary because the validity of the content of a statement cannot be separated from its featured mode of enactment. Any particular argument secures the content of its assertion by virtue of its validity claim, but the choice of a particular route to validity has consequences for the epistemic status of the claim, the interaction of participants in the argument, and the development of argumentation.

"Arguments are reasons proffered in discourse that redeem a validity claim", Habermas says $(1996,225)$. Validity claims are raised implicitly in every act of communication and are explicitly thematized in every argument. Put in its most basic form, "What is valid must be able to prove its worth against any future objections that might actually be raised" (ibid., 35). Defense is anticipated because the conditions of validity of an utterance are "something that cannot be shown by direct appeal to decisive evidence" (Habermas, 1993, 29). Rather, to achieve validity the rationality of an utterance-as-argument must be "recognized" as such by the interlocutor. Mutual recognition establishes the validity of an argument because "illocutionary goals" have been met. Interlocutors share the same conclusions for the same reasons, at once acknowledging and understanding the matter at issue.

Validity claims are sensitive to context and yet transcend the situated flow of communication. Questions of scope concerning for whom and under what conditions the truth, truthfulness, or correctness of an argument will remain warrantable are relevant considerations in determining validity. There is a generative question at the heart of the "fallible" process of argument: Must the argument be valid only for us, and only for the time being, or are we dealing with an issue where the conclusion must be valid always and for everyone? The reflexive condition of argument posits that the validity of a claim is relative to the conditions of communication under which it is recognized to be warranted.

The "thematizing" of arguments is a product of the varied, yet predictable, range of answers to the question of validity. In any argument, the "interests and objectives of actors" enter into discussion and define the "range of matters that are relevant" (Habermas, 1990, 135; emphasis removed). Argument is a common- 
place risk among interested, but fallible discussants that never can be entirely anticipated. "Dissension" is "fueled by disappointing experiences and surprising contingencies" (Habermas, 1996, 18). Thematizing is triggered by the launch of an "objection", a claim that "the utterance has failed" to fulfill a basic function, and a call to provide "grounds" or support for the statement. ("Grounds" are fully shareable and transparent; "support" comes from indirect evidence, such as the consistency between avowed intent and behavior offered to establish a sincerity claim.) Objections force discussants "into yes or no positions", the characteristic discursive arrangement of an argumentative exchange (Habermas, 1990, 19). The kinds of grounds and support offered, warrants made, backing drawn upon for authority, and obligations for genuine recognition-all these elements constitute the thematic configuration of particular forms of argumentation. But how does an utterance fail?

An utterance succeeds or fails as argument based upon the fulfillment of unique obligations or duties structured into its thematic development. Habermas developed the "types of argumentation" in his Theory of Communicative Action (1984, 1987 ) and has subsequently elaborated, refined, and critically deployed these categories of reasoning. Argument is comprised of two superordinate categories: "discourse" and "critique". The rationality of discourse is based on the connection of grounds to claim for a warranted reason. The rationality of critique is based upon confronting inconsistency productively. The distinction between argument as discourse and as critique appears similar to Toulmin's (1958) differentiation between warrant-using and warrant-establishing argument, in that the former discharges its burdens by proving a claim to be true, while the latter accomplishes its end by discovery of an unanticipated but acceptable reason.

Discourse is divided into theoretical and practical reason. Theoretical reason involves intersubjective claims to "truth" that comprise a consensually valid representation of the "objective world". Assertoric speech acts take the form of constative statements. Truth claims "must be capable of being defended with reasons against the objections of possible opponents and must ultimately be able to command the rationally motivated agreement of the community of interpreters as a whole" (Habermas, 1993, 53). Theoretical discourse also can take the complementary form of "purposive rationality". Such instrumental reasoning is constituted in trial and error, governed by experimental hypothesis, which enables the accumulation of empirical evidence and effective intervention into the natural world. Instrumental argument discerns efficient means to pregiven ends. Constative speech claims are fallible because a truth claim is a promissory note to the effect: a claim is true as best as we can ascertain, or until further objections are found. Propositions about the objective world may be found false in whole or detail. The principles upon which intervention into the natural world is conceived may be altered by experience and critical evaluation of errors (Habermas, 1984, 12-13). A signature of modernity, instrumental reasoning is quite powerful, but it is not the only game in town. 
Practical discourse engages questions of validity, too, but these arise in a distinct orientation to the world. Just as questions of truth interrogate the "objective world", moral and ethical questions interrogate the "social world", which according to Habermas is made up of the "totality of legitimately ordered interpersonal relationships". Here speech acts take the form of "regulative" statements in the interests of determining a viable order of living. Moral argument answers to questions of justice by invoking universal norms apt for a given situation. Moral arguments address how "we can regulate our common life in the equal interest of all" (Habermas, 1996, 161). What is right for everyone concerned in a matter where justice is at issue? This question cannot be answered completely unless all parties can, at least in principle, agree that a decision is rational. The partner of moral discourse, ethical-political argument, answers less universalizable questions of the good life by clarifying the needs and preferences emergent within a given community. In the social sphere, political and ethical arguments offer the common foci of discourse and critique in a pluralistic culture.

Just as argument generates insight in the social world, so it may be deployed to bring the subjective world, the domain of private experiences, into the realm of interpersonal relations. Since private experience is, after all, private, no direct, reciprocal evidence is available to test claims to truthfulness or sincerity. At best, interlocutors can learn to trust one another by matching word to deed, stated intention to actions performed. Critique purchases a claim to meaningful argument by reading failure or success in making the match. In The Theory of Communicative Action, Habermas explores two forms of critique (1984, 21-23). Aesthetic critique measures a work of art against the authentic expression of a form that becomes a subsequent model or standard of expression. Therapeutic critique involves argumentation in which an analyst places the professed claim to values alongside observations of behavior in order to provoke reflection on self-deception on the part of another person. Notably, critique-unlike discourse-does not presuppose "symmetry conditions". In discourse, symmetry is key. To reach an informed agreement both sides should have the equal opportunity and rational motivation to get all the issues on the table and make reasons perfectly transparent. In critique, reasons are never fully transparent. Note that ethical-political critique couples with discourse requirements to overcome traditions that stand in the way of realizing an individual or communal identity or to identify aesthetic innovations that set sensibility to novel form. Nevertheless, the best such a hermeneutic can do is to assess truthfulness from the consistency between avowed values and behavior, in promoting authentic recognition and genuine respect.

"It's really quite simple", Habermas writes, "whenever we mean what we say, we raise the claim that what we said is true, or right, or truthful. With this claim, a small bit of ideality breaks into our everyday lives, because such validity claims can in the end be resolved only with arguments. At the same time, we know that arguments that appear valid to us today can prove to be false tomorrow, in light of 
new experiences and new information" $(2003,47)$. Argument is an indispensable element of modernity because it accords humans the capacity and obligation to cooperatively "learn" from mistakes. Criticism engages, through argument, the question of whether a claim is any longer defensible in light of what we now know about the world, our relationships, and our selves; thus, to be rational is to be open to criticism--whether a claim is uttered as a description of a state of affairs, a selfreflexive injunction to act in the social world, or a public articulation or performance of exclusive experience.

\section{Validating Reasons}

Interlocutors can engage in critical argument only if legitimate communicative norms are acknowledged. Early in his career, Habermas elaborated these norms as forms of "communicative competence" in what he called an "ideal speech situation". Habermas (2001a) developed this theory of "universal pragmatics" into a critical program that works on gaining traction for the ideals of communication by hooking the general to the specific requirements of argument. At a universal level, there exist intuitively sensible and specifiable constraints as to what it means to engage in a serious argument; but for specific communities and institutions, constitutive rules of practice structure and regulate communicative engagement. In a given encounter, I believe, efforts to "harmonize" ideal norms of argument with the duties required by the special forms of reasoning generate public and institutional predicaments, situations where the force of the better argument sustains and struggles with cross-pressures. Below, I overview the constraining norms of argument presupposed in any "serious" effort directed toward conviction resulting in "mutual understanding". Second, I briefly examine the duties and obligations of two particular types of argument, moral and political-ethical discourse. Third, I develop a theory of argumentative predicaments, exploring the dynamics of competing and cooperative claims that generate controversy in particular situations.

\subsection{Universal Rules of Engagement}

At the broadest level, argumentation is regulated by the pursuit of mutual conviction based solely on "the force of the better argument". Interlocutors are compelled reciprocally to a conclusion as they become "rationally motivated" to an accord on a matter of mutual concern. As Thomas McCarthy puts it: "We are claiming, in other words, that the evidence and arguments are such that any rational, competent judge would come to the same conclusion; that if anyone should disagree, we could - if only he would let himself be guided by the force of the better argument-bring him to agree with us" (1978, 307-08). Serious arguments win assent through reflexive criticism because all negative forms of pressing consent such as external and internal "coercion" abort meaningful agreement. The constitution of affirmed conviction is not defined in any detail by Habermas, but he 
invites his readers to see "the force of the better argument" as an immanent characteristic of any genuine discursive engagement.

"Conviction" as a goal of conmunication is to be differentiated sharply from "influence" as an ambition of persuasion. At best, influence induces a particular agreement based on acquiescence to ulterior rewards for compliance, such as grants of money or power. At worst, the exercise of influence impairs the free exchange of reasons and autonomous judgment by distorting the conditions under which interpersonal argument takes place. "The four most important features", Habermas writes, "are: (i) that nobody who could make a relevant contribution may be excluded; (ii) that all participants are granted an equal opportunity to make contributions; (iii) that the participants must mean what they say; and (iv) that communication must be free from external and internal coercion" $(1998,44)$. These rules are similar to those proposed by the pragma-dialectical school, which has developed argument norms in considerably greater detail (van Eemeren and Grootendorst, 1984, 151-175).

\subsection{Moral and Political-Ethical Argumentation}

All argument ascribes to the common norms above; more specific validity conditions are attached to the functions of particular types of speech-act claiming. Assertoric claims promise knowledge of the objective world as to what is or could be the case. Regulative claims generate a "normative accord" concerning how arrangements of mutual living and pursuit of common goods should be established in the social world. Expressive claims articulate how trust can be sustained or recovered when addressing the subjective worlds among which individuals and within which communities have privileged access (Habermas, 1990, 28, 58-59). The distinction that interests Habermas the most is that between moral and ethical reasoning. William Rehg (1994) has developed an extended explication and analysis of these in relation to Habermas's discourse ethics. The following introduces some basic distinctions.

Moral Argument. Argument achieves "moral insight" when it shapes a consensus on what is justified and appropriate in a situation where the just course of action is at issue. In a pluralistic culture, tests of justice are uniquely complicated. It is crucial that moral reasoning situate its argumentation in common adherence to agreed upon procedure, without which a legitimate decision cannot be rendered. The universal norms of moral argument are to be distinguished from moral universalism, which in Habermas's view is too abstract and insensitive to the exigencies of situated interaction to provide appropriate guidance in the choice among apparently relevant interests. Rather, moral reasoning is embedded in discourses that follow the rules of the "argument game", as it were. Norms for moral argument include "impartiality", a stance of neutrality not entirely dissimilar from Rawls's original position, which assures a commitment to fairness. "Universalizability" requires that "the interest of all concerned" be taken into ac- 
count, either in actual discussion or as hypothetical future parties to the argument. "Reversibility" of the "perspectives from which participants produce this argument" is necessary to assure that the substantive norm of action under discussion is understood from the point of view of the other. "Reciprocity" guarantees equal consideration of the claims of each participant. Finally, "prescriptivity" is the requirement that each norm be tested for acceptability to future situations of this type. Thus, valid moral argument should guard against bias, partisanship, dogmatism, tokenism, and ad hoc commitments that impair claims of legitimacy by reducing confidence in the basic fairness of the procedure. In strong moral argument, interlocutors strive to establish a "valid norm" that "would meet with the approval of all concerned if they could take part in a practical discourse" (Habermas, 1990, 121; also 119-125).

Ethical-Political Argument. The norms of ethical-political argument are designed to facilitate the deliberations of a particular individual or community over questions of the common good. Within the tradition of a community, arguments about values are raised in contexts of identity. Interpretations of who we are, in light of who we would become, are advanced. Such comparisons depend upon "clarification" of professed values and historical realizations. Argument is an engaged hermeneutic that critically compares and contrasts professed grants of rights, protection of freedoms, and fair distribution of goods against the experiences of all members of the community. The test of argument focuses on whether the order of values is reflective of the needs of the community, and needs change as social configurations render inequalities more visible. The outcome of argument is whether particular forms of life (ways of doing things, traditions, customs of socialization and social reproduction) should be renewed or devalued in the context of current relationships and the long-term good of the community. The norms of politicalethical argument within a community would appear to be similar to those of moral reasoning, with the exception that constitutional guarantees of communication rights themselves furnish norms for deliberative and legal communities that concretely govern best practices. Freedoms of speech, assembly, association, and conscience thus become standards against which are measured practices of fairness, inclusion, participation, and sensitivity in determining the distribution of goods, duties, and freedoms, and assumption of risks, within a community.

Between communities, ethical-political activities take the form of bargaining. Bargaining is like argumentation insofar as its aim is to enable the formation of something like a consensus and it is constituted in an exchange characterized by offense and defense of yes/no positions. Unlike argumentation, a satisfactory bargaining outcome can be a consensus in which parties agree to abide by a common decision for different reasons. "As participants in 'discourses,' we want to arrive at shared opinions by mutually convincing one another about some issue through arguments, whereas in 'bargaining' we strive for a balance of different interests" (Habermas, 2001b, 116-117). Bargaining appears to be that communicative condi- 
tion where argumentation presupposes common cause rather than common ground. One thinks here of feminists and fundamentalists who agree in common to fight pornography, both interested in closing down specific enterprises, but each with far different reasons derived from the communities served by the action; the bargain struck is a limited partnership in the pursuit of a common end. More often, bargaining may resemble strategic action where parties exchange threats and promises in accord with their conflicting interest and relative position of power in order to impose their will on the other. However, unlike strategic action, whose calling card is deception, bargaining divides up goods by constructing an informed assessment of relative strength, rather than by dramatizing intent with illusory posturing. Thus, political-ethical argument does not necessarily abort when discourse fails to "convince all parties in the same way"; rather, "a compromise can be accepted by different parties each for its own different reasons", thereby engaging "the more or less cunning realization of perlocutionary effects" (Habermas, 1996, 166). In the end, the norms of bargaining are special cases of those of argument; to reach an agreeable settlement, parties must find the outcome "fair"--a determination that can only be reached through discourse.

\subsection{The Predicaments of Argumentation}

In private and public, as matters of the sciences, arts, or politics, communicative action constitutes the ordinary condition of interchange among people. The habits, skills, and practices necessary to communicate are acquired through interaction and development. In such activities, human beings exchange and infer reasons, which for Habermas are not a "disposition to have opinions", but the very "currency used in discursive exchange that redeems criticizable validity claims" (Habermas, 1996, 35). As such, all reasons are "double edged from the word go", transmitting the potential to "reinforce and upset beliefs" (ibid.), including undoubtedly orientations to the conduct of communication. In everyday arguments, reasons routinely challenge or confirm the truth of what is claimed, the effectiveness of a proposed means to an end, the rightness of an invoked prohibition or permission, the value of a tradition, the strength of a need, the claim of authentic representation of a private experience. The standards of valid argument, from basic rules between speaker and hearer, to the special conditions of justice, to the contingent regulations of community needs, to the give and take of bargaining, offer a wide variety of choice from which to critique and engage a controversy. The double-edged potential of reasons, affirming and objecting to the obligations incurred in making meaningful speech acts, generate the validity predicaments of controversy.

Habermas's critical theory is mobilized for engaging debates in which communicative reasoning and argumentation must satisfy competing validity requirements, in which the demands for rationality are urgent but the resources for consensus limited. In such encounters, the "force of the better argument" splits into multiple 
vectors, each of which presses argument in alternative directions, with sometimes competing, sometimes cooperating or "overlapping" thresholds for belief and standards of validity. Does the moment at hand essentially invite a discourse of justice, identity, interest, risk, goods, or rights? Or does the moment essentially require a critique of self-deception, distortion, pathology, repression, prejudice, or spectacle? Predicaments arise in those complex exchanges where discourse and critique are entwined and the requirements of how best to regard the interests of reasoning and obligations of communication are contested; such predicaments pervade all modern controversies, and characteristic predicaments routinized into communicative practices sustain the dynamics of social institutions, epistemic fields, and public fora. Although Habermas $(1984,23)$ recognizes that the "well-formedness" of a discourse invites a type of argument itself characteristic of semantic analysis, I would assert that the contestation over the grounds upon which communication is developed or support attributed is itself part of the turbulent development of reason in society. Intervention into social controversies requires a critical reconstruction of the dynamics whereby alternative validity requirements offer opportunities and constraints, risk and security, in the construction of argument. To illustrate how Habermas engages social controversies, I will discuss a prominent predicament in the politics of discourse.

\section{The Case of Communicative Power}

The public sphere is an arena in which the "force of the better argument" underwrites the practices of deliberative democracy. Famously, Habermas argued in his inaugural work that the public sphere is in a state of decline, corrupted by the interests of money and power, its news organs given over to spectacle rather than debate (1989/1962). Published in Germany during the New Left movements of the 1960 s, the declinist thesis was a controversial basis for critique of Cold-War democracies. Released in an English-language version at the end of the Cold War, Habermas's declinist thesis sparked a decade of interdisciplinary debate (Calhoun, 1992; Goodnight and Hingstman, 1997). A social theory of argument, however, reads the state of reason against the flow of history, and the structure of Habermas's contemporary writings on the public sphere appear to be adapted to the success of the revolutions in Eastern Europe, with the return of the public sphere in the shape of peaceful transitions of power. If the public sphere is back, the theorizing of political controversy in the post-Cold War era is cast with a sophisticated eye toward the relationships among new social movements, constitutional states, and market forces. "Deliberative politics", Habermas concludes, "lives off the interplay between democratically institutionalized will-formation and informal opinionformation" $(1996,308)$. In short, the legitimizing discourses of modern democratic governments are the product of oscillating arguments between insurgent social movements and the efforts of the social welfare state-the former aiming at promoting change to mitigate the excesses of the market system, the latter trying 
to stave off crises promulgated by growing inequalities of wealth. In this debate, characteristic predicaments arise for both sides.

Deliberative democracy engages the topics of "the good life, collective identity, and need interpretation". Individuals and groups enter "from the fringes" to articulate new needs rendered urgent by changing economic and social conditions. The unregulated public sphere is the space of spontaneous public opinion. This sphere is "an open and inclusive network of overlapping, subcultural publics having fluid temporal, social, and substantive boundaries" (ibid., 307). Characteristically, new social movements ground arguments in a "context of discovery". Absent institutional obligations, participants in new social movements are freer to argue from positions where "new problem situations can be perceived more sensitively", discourses of "self-understanding" can be "conducted more widely and expressively", and "collective identities and need interpretations can be articulated with fewer compulsions than is the case in procedurally regulated public spheres" (ibid., 308). The strength of the truth is the achievement of "communicative power", a form of "solidarity" born of shared, transparent convictions that change is imminent. One thinks of the Velvet Revolution where, when the time was ripe, the rotten regime fell because everyone discovered that it lacked legitimacy. Habermas's idea of "communicative power" is adapted from Arendt's notion of "natality", where newly minted convictions, with an undistorted clarity, articulate consensual change (ibid., 147-151). Some movements may achieve great things, yet Habermas is also aware that the "anarchic" convergence of public opinion can as well be given over to rumor, and become a source of misinformation, oppression, and a pretext for intervention by institutions (ibid., 307-308). The predicament of any "context of discovery" is to keep deliberations fresh and focused ultimately on what is good for the public in the long run, without devolving the movement into a contest among factions.

"Administrative power" complements "communicative power". When government does its job, the state secures legitimacy by regulating market forces, incrementally adjusting policy, and sustaining a justice system. This is the process of systemic rationalization, balancing the excess of the market against the interests of the public. Against criticisms from both sides, state communications are invested heavily in discourses of justification. Optimally, governments would deploy resources in such a way as to pare inefficient policies and "establish and guarantee living conditions in the equal interests of all citizens" (ibid., 339). In Habermas's view, democratic state power performs a crucial function in protecting freedoms and rights. Legitimate state authority is requisite to assuring constitutive guarantees of communicative rights and the administration of social welfare, each of which would prove evanescent in an unorganized public sphere. Typically, however, administrative institutions "develop their own internal systemic logics and push the citizen into the peripheral role of mere organization member. As selfregulating systems, economy and administration tend to close themselves off from 
their environments and obey only their internal imperatives of money and power" (ibid., 505; also Habermas, 1987). Institutions are at some level always aware of "latent" requirements of public support. When a gap emerges between acceptable public justifications of administrative decisions and the internal dynamics that determine resource distributions and regulations, institutions often turn to public relations experts to curry public favor. Habermas believes that propaganda is not likely to be effective, especially in times of legitimation crisis, because once propagandistic practices become evident to the public, institutional discourse loses legitimacy. Thus, the predicament of any public institution is how to innovate justifications to adapt to public demands while slowly pruning internal logics of money and power that would spiral into self-serving and self-insulating operations.

The predicaments of communicative and administrative powers are not unbridgeable. Habermas identifies mediating processes that span the gap between the convincing but unorganized innovations of the public sphere, and the justified but ossified political discourses of administration. For new social movements, the fora of civil society offer places where innovative interpretations of needs, identities, values, and freedoms become translated into widespread and mainstream social concerns. At this point, strategies of influence that bring the new news about needs to notice are appropriate. For administrative institutions, legislative debate furnishes a place where the opinion swells of civil-social causes become translated into new justifications and directions for administrative activity. Deliberative democracy in legislative debate requires a bargaining where the conflicting vectors of communicative power are negotiated. In the end, Habermas moves from a declinist thesis to a view that sees the relation between state and periphery. "In periods of mobilization, the structures that actually support the authority of an engaged public sphere begin to vibrate. The balance of power between civil society and the political system then shifts" (Habermas, 1996, 379).

The dialectic between communicative power and administrative power is a major site of argumentative predicaments. There are likely as many other unique dynamics of argumentation as there are emergent controversies. In the controversies over human rights, the West must find a way simultaneously to pursue selfcriticism for utilizing the ideology of rights as a cover for imperialism, while defending the universalism that underwrites openness to criticism (Habermas, 2001b). In the controversies over genetic engineering, the market forces that will carry innovation in scientific research must be acknowledged while developing norms unique to a logic of remedy that would preserve the treatment of people as ends (Habermas, 2003). In the debate on the Holocaust, a way to position understanding of the complicity of a preceding generation and the ramifications of the monstrosity of genocide must be found while translating personal shame into a public stance. While Habermas has yet to develop an independent theory of argument criticism, it is clear that he deploys his philosophical perspective to excavate, 
explain, evaluate and intervene into controversy. In each case, the aim appears to keep open the possibilities of an expanding domain of communication.

\section{Conclusion}

The Habermasian perspective on communicative reasoning opens the way toward a larger discussion of argumentation and social theory. The space for such a discussion within argumentation studies more broadly conceived has been opening for some time. On the one hand, scholars have made great progress in developing the norms of reason in communication along the lines of dialogical principles articulated by the pragma-dialectical school (van Eemeren and Grootendorst, 1984, 304-305). Similarly, informal logic has explored particular distortions of reasoning and communication by exploring traditional fallacies in such a way as to call attention to barriers to clear thinking and problems in judgment. Critical thinking as one outcome of concern with informal logics serves emancipatory ends by sharpening citizens' ability to pick out the distortions of reasoning that are routinely practiced by the mass media. Integrative work among critical theory and these normative movements would be useful to the investigation of communities of practice, institutional constraints, and emergent publics.

On the other hand, scholars have made significant progress in critical engagement of public argument. The "good reasons" tradition, for example, has not only generated productive criticism, but also evolved forms of valid argument in narrative (Wallace, 1963, Fisher, 1978). Ideological and contextual critiques of public argument in the evolution of counterpublic spheres, technical expertise, and new social movements are expanding (see for example, Charland, 1987; McGee, 1975; Wander, 1984). Yet, rhetorical studies appear detached from how cumulative practices of influence impact possibilities of communication.

Just as Habermas himself has not yet explicitly constructed a theory of argument criticism, so the field of argument studies has yet to embark on the great project of explicitly integrating its contemporary lines of normative theory with diverse communities of practice. It is likely the case that the great controversies of a day are sites where, through argumentation, the capacity of human communication is being stretched, changed, and developed through testing social, political, and cultural frames of reasoning. The integration of normative and critical work is requisite to learning about argumentation in its multiple patterns of practice, developments, and formations.

The direction of a future critical theory of controversy most likely resides in those predicaments where the needs for communication are urgent and its prospects dim. Thus, argumentation is called upon as a "court of appeal" to mediate with "good reasons" questions crucial to strangers who must find a way to live together under tides of globalizing change. "Good reasons" are rarely enough, Habermas never tires of telling us; rather, the practices of communication thrive in 
the long run only under constitutional and democratic guarantees. Exercising these rights and duties enable citizens to learn to correct past mistakes through deliberation; conversely, the critical practice of argument requires critique of all theories and practices that would substitute reflectively discerned convictions for those reasons that cannot withstand public scrutiny. In this respect, the tasks of a social theory of argument must always remain unfinished, for its goals traffic with ideals. Yet, as Holub reminds us: "For Habermas, the more bits of ideality trickle down into our everyday life, the more we communicate effectively with others, and the more we grow in the understanding of ourselves and others. This allows us to become more mature and emancipated agents, and ultimately, more rational citizens" $(1991,47)$. Nothing less is the aim of a critical theory of controversy.

\section{References}

Bernstein, R. J. (1976). The Restructuring of Social and Political Theory. New York: Harcourt Brace Jovanovich.

Bohman, J. (1995a). Critical Theory. Cambridge Dictionary of Philosophy (p. 170). Cambridge: Cambridge University Press.

Bohman, J. (1995b). Frankfurt School. Cambridge Dictionary of Philosophy (pp. 278279). Cambridge: Cambridge University Press.

Borradori, G. (2003). Philosophy in a Time of Terror: Dialogues with Jürgen Habermas and Jacques Derrida. Chicago: University of Chicago Press.

Brockriede, W. (1977). Characteristics of Argument and Arguing. Journal of the American Forensic Association, 13, 129-132.

Brockriede, W. (1975). Where is Argument? Journal of the American Forensic Association, 11, 179-182.

Burleson, B. R. (1979). On the Foundations of Rationality: Toulmin, Habermas and the A Priori of Reason. Journal of the American Forensic Association, 16, 112-126.

Calhoun, C. (1992). Habermas and the Public Sphere. Cambridge, MA: MIT Press.

Charland, M. (1987). Constitutive Rhetoric: The Case of Peuple Québecois. Quarterly Journal of Speech, 73, 133-150.

Cushman, D.P. and D. Dietrich. (1979). A Critical Reconstruction of Jürgen Habermas' Holistic Approach to Rhetoric as Social Philosophy. Journal of the American Forensic Association, 16, 128-137.

Cox, R. J. and C. A. Willard. (1982). Introduction: The Field of Argumentation. In R. J. Cox and C. A. Willards (Eds.). Advances in Argumentation (pp. xiii-xlvii). Carbondale: Southern Illinois University Press.

Eemeren, F. H. van, R. Grootendorst, F. Snoeck Henkemans, et al. (1996). Fundamentals of Argumentation Theory. Mahwah, NJ: Erlbaum.

Eemeren, F. H. van, and R. Grootendorst. (1984). Speech Acts in Argumentative Discussions: A Theoretical Model for the Analysis of Discussions Directed Towards Solv- 
ing Conflicts of Opinion. Dordrecht, Holland; Foris.

Farrell, T. B. (1979). Habermas on Argumentation Theory: Some Emerging Topics. Journal of the American Forensic Association, 16, 77-81.

Fisher, W. R. (1978) Toward a Logic of Good Reasons. Quarterly Journal of Speech, 64, 376-384.

Goodnight, G. T. and D. B. Hingstman. (1997). Studies in the Public Sphere. Quarterly Journal of Speech, 83, 351-370.

Habermas, J. (1971). Knowledge and Human Interests (J. J. Shapiro, Trans.). Boston: Beacon.

Habermas, J. (1973). Theory and Practice (J. Viertel, Trans.). Boston: Beacon.

Habermas, J. (1979). Communication and the Evolution of Society (T. A. McCarthy, Trans.). Boston: Beacon.

Habermas, J. (1981). The Theory of Communicative Action. Vol. 1: Reason and the Rationalization of Society (T. McCarthy, Trans.). Boston: Beacon.

Habermas, J. (1983). The Theory of Communicative Action. Vol. 2: Lifeworld and System (T. McCarthy, Trans). Boston: Beacon.

Habermas, J. (1988). On the Logic of the Social Sciences (S. W. Nicholsen and J. A Stark, Trans.). Cambridge, MA: MIT Press.

Habermas, J. (1989/1962). The Structural Transformation of the Public Sphere: An Inquiry into a Category of Bourgeois Society (T. Burger, Trans.). Cambridge, MA: MIT Press. Originally published in 1962.

Habermas, J. (1990). Moral Consciousness and Communicative Action (C. Lenhardt and S. W. Nicholsen, Trans.). Cambridge, MA: MIT Press.

Habermas, J. (1992). Postmetaphysical Thinking (W. M. Hohengarten, Trans.). Cambridge, MA: MIT Press.

Habermas, J. (1993). Justification and Application (C. P. Cronin, Trans.). Cambridge, MA: MIT Press.

Habermas, J. (1996). Between Facts and Norms: Contributions to a Discourse Theory of Law and Democracy (W. Rehg, Trans.). Cambridge, MA: MIT Press.

Habermas, J. (1998). The Inclusion of the Other: Studies in Political Theory (C. Cronin and P. De Grieff, Eds.). Cambridge, MA: MIT Press.

Habermas, J. (2001a). On the Pragmatics of Social Interaction: Preliminary Studies in the Theory of Communicative Action. (B. Fultner, Trans.). Cambridge, MA: MIT Press.

Habermas, J. (2001b). The Postnational Constellation: Political Essays (M. Pensky, Trans.). Cambridge, MA: MIT Press.

Habermas, J. (2002a). Religion and Rationality: Essays on Reason, God, and Modernity (E. Mendieta, Ed.). Cambridge, MA: MIT Press.

Habermas, J. (2002b). The Liberating Power of Symbols (P. Dews, Trans.). Cambridge, MA: MIT Press.

Habermas, J. (2003). The Future of Human Nature. Cambridge: Polity Press.

Holub, R. C. (199I). Jürgen Habermas: Critic in the Public Sphere. London: Routledge. McCarthy, T. (1978). The Critical Theory of Jürgen Habermas. Cambridge. MIT Press. 
McGee, M. C. (1975). In Search of the 'People': A Rhetorical Alternative, Quarterly Journal of Speech, 6I, 235-249.

Naess, A. (1953). Interpretation and Preciseness: A Contribution to the Theory of Communication. Oslo: I kommisjon hos J. Dybwad.

Perelman, C. and Olbrechts-Tyteca, L. (1969). The New Rhetoric: A Treatise on Argumentation (J. Wilkinson and P. Weaver, Trans.). Notre Dame: University of Notre Dame Press.

Pusey, Michael. (1987). Jürgen Habermas. Chichester [West Sussex]: E. Horwood; Tavistock.

Rehg, W. (1994). Insight and Solidarity: A Study in the Discourse Ethics of Jürgen Habermas. Berkeley, CA: University of California Press.

Rehg, W. (1997). Reason and Rhetoric in Habermas's Theory of Argumentation. In W. Jost and M. J. Hyde (Eds.), Rhetoric and Hermeneutics in Our Time (pp. 358-377). New Haven, CT: Yale University Press.

Toulmin, S. E. (1958). The Uses of Argument. Cambridge: Cambridge University Press.

Wallace, K. R. (1963), The Substance of Rhetoric: Good Reasons. Quarterly Journal of Speech, 49, 239-249.

Wander, P. (1984). The Third Persona: An Ideological Turn in Rhetorical Theory. Central States Speech Journal, 35, 197-216.

Wenzel, J. W. (1979). Jürgen Habermas and the Dialectical Perspective on Argumentation. Journal of the American Forensic Association, 16, 83-94.

Wenzel, J. W. (1990). Perspectives on Argumentation: Rhetoric, Dialectic, Logic. In R. Trapp and J. Schuetz (Eds.), Perspectives on Argumentation: Essays in Honor of Wayne Brockriede (pp. 9-26). Prospect Heights, IL: Waveland.

Wenzel, J. (1993). Cultivating Practical Reason: Argumentation Theory in Postmodernity. In R. McKerrow (Ed.), Argument and the Postmodern Challenge: Proceedings of the Eighth SCA/AFA Conference on Argumentation (pp. 1-7). Annendale, VA: SCA.

G. Thomas Goodnight Annenberg School for Communication University of Southern California 3502 Watt Way Los Angeles, CA 90089-0281 email:gtg@usc.edu 